Kinoshita, J. H. \& Wachtl, C. (r958). f. biol. Chem. 233, 5 .

Lee, O. S. \& Hart, W. A. (1944). Amer. F. Ophthal. 27, 488 .

Lerman, S. (I959). A.M.A. Arch. Ophthal. 6r, 88.

McLaren, D. S. (1960). Proc. Nutr. Soc. 19, 89.

Morton, R. A. (1944). Nature, Lond., 153, 69.

Noell, W. K. (1955). Amer. F. Ophthal. 40, no. 5, part 2, p. 60.

Oomen, H. A. P. C. (1958). Fed. Proc. 17, Suppl. no. 2, p. III.

Pirie, A. (1948-9). Brit. F. Nutr. 2, I4.

Rodger, F. C. (1960). Proc. Nutr. Soc. r9, 80.

Rushton, W. A. H. (1953). Acta physiol. scand. 29, 16.

Rushton, W. A. H. (1956). F. Physiol. 134, ir.

Rushton, W. A. H. (1958). Nature, Lond., 182, 690.

Schwarz, V. \& Golberg, L. (I955). Biochim. biophys. Acta, 18, 310.

Smelser, G. K. (1952). A.M.A. Arch. Ophthal. 47, 328.

Smelser, G. K. \& Chen, D. K. (1955). A.M.A. Arch. Ophthal. 53, 676.

Sydenstricker, V. P., Sebrell, W. H., Cleckley, H. M. \& Kruse, H. D. (1940). F. Amer. med. Ass. Ir4, 2437.

van Heyningen, R. (1959). Nature, Lond., 184, 194.

Wald, G. (1935). F. gen. Physiol. 19, 35x.

Wald, G. (1954). Science, rr9, 887 .

Wald, G., Brown, P. K. \& Smith, P. H. (1954-5). F. gen. Physiol. 38, 623 .

Wood, D. C., Massi, L. \& Solomon, E. L. (1959). 7. biol. Chem. 234, 329.

The following reviews, not mentioned in the text, contain further relevant information:

Dartnall, H. J. A. (1957). The Visual Pigments. London: Methuen.

Morton, R. A. \& Pitt, G. A. J. (1957). In Progress in the Chemistry of Organic Natural Products, 14, 245. (L. Zechmeister, editor.) Wien: Springet Verlag.

Pirie, A. \& van Heyningen, R. (1956). Biochemistry of the Eye. Oxford: Blackwell's Scientific Publications.

Wald, G. (1957). In Modern Problems of Ophthalmology, x, 173.

Wald, G. (1958). Science, 128, 1481 .

\title{
The crystalline lens in human and experimental malnutrition
}

\author{
By D. S. McLaren, East African Institute for Medical Research, Mwanza, \\ Tanganyika
}

Human cataract constitutes an outstanding problem from the point of view of aetiology, prevention and treatment amongst all races. It is assuming an increasingly important place, as congenital cataract remains in the hard core of little-understood congenital conditions, and as more and more people live long enough to develop senile cataract.

Several decades ago the discovery of such interesting facts as the very high concentrations of ascorbic acid, glutathione, and inositol in the normal lens, and the experimental production of lens changes in animals by diets deficient in riboflavin (Day, Langston \& O'Brien, I93I) or certain amino acids (Totter \& Day, I942; Hall, Bowles, Sydenstricker \& Schmidt, I 948) led only to false hopes that human cataract might be readily prevented by dietary means. Today the cataractous process interests biochemists, physiologists, electron microscopists and nuclear physicists, and nutritional aspects of the condition are being studied from fresh points of view. 
Work undertaken in the Human Nutrition Research Unit at Mill Hill has shown that prolonged dietary deficiency of protein results in lowering of the content of sulphydryl groups in the lens in both rats and pigs (Bagchi, 1959). In addition, pigs that survived for more than a year on diets very deficient in protein developed bilateral cataract as well as many of the classical signs of protein malnutrition seen in children (McLaren, 1959). In another experiment, protein deficiency in a rat dam, of a degree usually held to be incompatible with the survival of the foetus, resulted in bilateral congenital cataract in each of the four offspring (McLaren, 1957). It has not been possible to repeat the conditions of this experiment and causal relationship between maternal protein deficiency and cataract in the offspring has not yet been established. These results did, however, suggest that examination of the lenses of young children in a malnourished community might be rewarding.

It has long been known that the appearance of water clefts in the cortical portion of the lens is one of the commonest manifestations of incipient cataract. It usually takes several years for these clear clefts filled with water to become cloudy as a result of the deposition of myelin. In this way wedge-shaped opacities, with the base of the wedge situated peripherally, are formed and gradually increase in size and coallesce to produce the immature stage of cataract. These changes are most exceptional in the earlier decades of life. Pfeiffer ( $192 \mathrm{I}$ ) found that in I I I people $28 \%$ of those about 50 years of age, and $37 \%$ of those who were older, showed water clefts.

The routine examination of many Africans of all ages for various eye complaints during the whole of 1958 and the first half of 1959 revealed the almost universal presence of spoke-like opacities in the lens. The discovery of these changes, even in the young, led to the examination of large numbers of schoolchildren.

So far eye examinations have been carried out in two areas of Tanganyika. The first is in the dry Central Province around Mvumi, where shortage of food has been a constantly recurring problem, the last famine having been in 1953 and 1954 . The second survey has been undertaken in villages situated in Mwanza district, no part of which is far from Lake Victoria, where the rainfall is usually adequate and where food supplies are much more abundant. The lenses of primary schoolchildren were examined by one observer for the occurrence of spoke-like opacities whilst measurements of refraction were being carried out under complete hyoscine cycloplegia with an electric retinoscope. All the children were between the ages of 7 and 14 years. Some of the more marked cases were also examined under the slit-lamp microscope and the spokes were found to be located usually in both the anterior and posterior cortex, and although appearing to be subcapsular, owing to an optical illusion, they were probably deeper.

A rough system of scoring was used, based upon the number of spokes in each eye and their size and density. The maximum score for each was 6 . Table I shows the percentages of children in the two areas with different degrees of spoke formation.

In this analysis adjacent odd and even scores have been combined as there was a uniform tendency for the observer to be biased towards even rather than odd scoring. 
Table I. Incidence of spoke formation in schoolchildren in Tanganyika

\begin{tabular}{|c|c|c|c|c|c|c|c|c|}
\hline \multirow[b]{2}{*}{ District } & \multirow[b]{2}{*}{ No. examined } & \multicolumn{7}{|c|}{ Percentage of children with score* } \\
\hline & & ○ & I or 2 & 3 or 4 & 5 or 6 & 7 or 8 & 9 or 10 & 11 or 12 \\
\hline Mwanza & $55 \mathrm{I}$ & $2 I \cdot 6$ & $17 \cdot 9$ & $22 \cdot 5$ & $17 \cdot 6$ & 10.2 & $7 \cdot 2$ & $3 \cdot 0$ \\
\hline Mvumi & 869 & $14 \cdot 8$ & $16 \cdot 2$ & $32 \cdot 7$ & $23 \cdot 6$ & $9 \cdot 4$ & $2 \cdot 9$ & 0.3 \\
\hline
\end{tabular}

Though the mere presence or absence of spoke formation can be determined with considerable accuracy and observations are readily reproducible, the degree of change present can be estimated only in a very rough fashion, and the results shown in Table I are not suitable for detailed analysis. It does appear, however, that although the higher incidence of spoke formation was found in Mvumi $\left(\chi^{2}=10.68 ; P \sim 0.001\right)$ there were more with the most marked degree of change in Mwanza.

At present it is impossible to say anything definite about the aetiology of these interesting lens changes. Further examinations are being carried out on children of other population groups, and although the work is incomplete it can be stated that European children of the same age and who have spent most of their life in Africa do not show the same changes. Histological and biochemical studies of the lenses of Africans which we have recently begun are in too early a stage to report upon. If this very high incidence of lens opacities at such an early age in the African is related to the eventual development of cataract in later years then it may constitute evidence in favour of the widely held belief that cataract occurs at an earlier age in the tropics than it does in some other parts of the world. Whether or not malnutrition is at work is an open question at the moment.

\title{
REFERENCES
}

Bagchi, K. (1959). Indian f. med. Res. 47, 184 .

Day, P. L., Langston, W. C. \& O’Brien, C. S. (I93I). Amer. F. Ophthal. 14, 1005.

Hall, W. K., Bowles, L. L., Sydenstricker, V. P. \& Schmidt, H. L. Jr. (I948). \%. Nutr. 36, 277.

McLaren, D. S. (1957). Proc. Nutr. Soc. 16, xxiii.

McLaren, D. S. (1959). Brit. F. Ophthal. 43, 78.

Pfeiffer, C. E. (1921). v. Graefes Arch. Ophthal. 107, 7 I.

Totter, J. R. \& Day, P. L. (1942). F. Nutr. 24, I 59.

\section{Personal observations on some metabolic diseases of the eye}

\author{
By F. C. Rodger, University Laboratory of Physiology, Oxford
}

The observations presented here were made by me as an oculist in tropical countries, dating back to 1945 . These countries include Burma, India, Ceylon, Egypt, Ghana, Nigeria, the Cameroons and certain areas in central Africa under French control. The opportunity to witness a relationship between malnutrition and the eye has been unlimited as a result. The points now to be mentioned are all based on personal work-in some instances with collaborators. 